\section{Pyroligneous Acid Improves In Vitro Rooting of Japanese Pear Cultivars}

\author{
Masanori Kadota, Takashi Hirano, and Kiyotoshi Imizu \\ Toyama City Agricultural Center, 3-105 Tsukioka-cho, Toyama 939-8142 \\ Japan
}

\section{Yoshiji Niimi}

Faculty of Agriculture, Niigata University, 2-8050, Ikarashi, Niigata 950-2181, Japan

Additional index words. Pyrus pyrifolia, rooting frequency, shoot proliferation, wood vinegar

\begin{abstract}
Effects of PA on in vitro shoot proliferation and root formation were investigated using shoot cultures of three Japanese pear (Pyrus pyrifolia Nakai) cultivars. PA inhibited shoot multiplication and promoted initiation and development of roots in the cultured shoots of three cultivars, resulting in increasing the proportion of rooted shoots. Chemical name used: pyroligneous acid (PA).
\end{abstract}

Pyroligneous acid (PA) (wood vinegar) is a dark brown solution obtained as a by-product of wood carbonization. It contains over 200 components, such as acids, alcohols, phenols, and neutrals (Jodai et al., 1989; Shirakawa et al., 1995b; Yatagai et al., 1988). PA accelerates seed germination of garland chrysanthemum (Chrysanthemum coronarium L.), honewort (Cryptotaenia japonica Hassk.) and lettuce (Lactuca sativa L.) (Uehara et al,. 1993), seed germination and plantlet growth of chinese cabbage (Brassica campestris L.) and rice (Oryza sativa L.) (Yatagai and Unrinin, 1987), root (Tsuzuki et al., 1989) and plant (Ichikawa and Ota, 1982; Shirakawa et al., 1995a) growth of rice seedlings, and root formation of sweet potato (Ipomoea batatas Poir.) plantlets (Du et al., 1998). This study investigated PA influences on shoot proliferation and root formation of in vitro shoots of Japanese pear (Pyrus pyrifolia N.) cultivars.

\section{Materials and Methods}

Plant materials. Shoots of Japanese pear 'Hosui', 'Kosui', and 'Shinko' were subcultured monthly for 12 months on a shoot proliferation medium consisting of halfstrength MS (Murashige and Skoog, 1962) with $0.5 \mu \mathrm{M}$ indole-3-butyric acid (IBA), $4.4 \mu \mathrm{M}$ N6-benzyladenine, $58.5 \mu \mathrm{M}$ sucrose and $0.8 \%$ powder agar (Wako Co., Tokyo). They were incubated at a $16-\mathrm{h}$ photoperiod illuminated by a cool-white fluorescent light $\left(50 \mu \mathrm{mol} \cdot \mathrm{m}^{-2} \cdot \mathrm{s}^{-1}\right)$ at $25^{\circ} \mathrm{C}$ in a tube $(25 \times$ $100 \mathrm{~mm}$ ) with $10 \mathrm{~mL}$ of gelled medium.

Preparation of $P A$. The $\mathrm{PA}$ used in this study was manufactured at Toyama City Agricultural Center. Pruned branches of Japanese pear were cut during winter, were put in a greenhouse and were dried by natural wind for $2-3$ weeks. Then, they were placed inside an iron kiln $\left(0.75 \mathrm{~m}^{2} \times 2.5 \mathrm{~m}\right)$ and were dried

Received for publicaiton 18 Oct. 2000. Accepted for publication 6 June 2001. by distillation. The distillation duration was $\approx 10 \mathrm{~h}$ and the rate of temperature increase was $2{ }^{\circ} \mathrm{C}$ per min., with maximum temperature of $\approx 500^{\circ} \mathrm{C}$. Crude PA was obtained as a dripping solution from the base of an opening of a gas spillage and was kept for 6 months in a dark, cool room. The top clear layer was removed from the deposited tar by filtering through a coffee filter paper (Karita Co., Tokyo) and was used in the following experiment.

Shoot proliferation and rooting investigation. To investigate the effect of PA on shoot proliferation, shoot tips were transferred to a proliferation medium containing $0 \%, 0.001 \%$, $0.01 \%$, or $0.1 \%$ (v/v) PA. The number of new shoots formed from each initial shoot and the rate of fresh weight increase after $30 \mathrm{~d}$ were recorded. To investigate the effect of PA on rooting, $10 \mathrm{~mm}$ shoot tips were cut and transferred to a root initiation medium consisting of half-strength MS with $4.9 \mu \mathrm{M}$ IBA, $58.5 \mu \mathrm{M}$ sucrose, $1.35 \mathrm{~mm}$ phloroglucinol $(1,3,5$ trihydroxybenzene), $0.8 \%$ powder agar and $0 \%, 0.001 \%, 0.01 \%$ or $0.1 \%(\mathrm{v} / \mathrm{v}) \mathrm{PA}$ and were kept in the dark at $25^{\circ} \mathrm{C}$. After $5 \mathrm{~d}$, they were transferred to the same medium without IBA (root development medium). Rooting frequency, the average root length and survival rate were recorded after $45 \mathrm{~d}$. All media were adjusted to $\mathrm{pH} 5.7$ and were autoclaved at $121{ }^{\circ} \mathrm{C}$ for $20 \mathrm{~min}$. The PA solution was adjusted to $\mathrm{pH} 5.7$ using $1.0 \mathrm{~N} \mathrm{NaOH}$, and the PA solution and phloroglucinol were filtersterilized and were added to the medium after autoclaving. All cultures were incubated at a 16-h photoperiod illuminated by a cool-white fluorescent light $\left(50 \mu \mathrm{mol} \cdot \mathrm{m}^{-2} \cdot \mathrm{s}^{-1}\right)$ at $25^{\circ} \mathrm{C}$ in a plastic jar $(5 \times 15 \mathrm{~cm})$ with $30 \mathrm{~mL}$ of gelled medium.

Statistical analysis. For each investigation, five jars, each with four shoots, were used and treatments were arranged as a randomized complete block. The data were analyzed using analysis of variance (ANOVA) with mean separation by least significant difference (LSD) at $P \leq 0.05$. For the experiment on shoot proliferation the number of shoots formed by each explant and the increased in fresh weight were subjected to a two-way ANOVA with PA concentrations and cultivars. For the experiment on rooting, the rooting frequency, average root length and the survival rate of shoots were analyzed using two-way ANOVA with PA concentrations and cultivars. Also, all investigation items had regression curves drawn using the concentration of PA as the standard.

\section{Results and Discussion}

Shoot proliferation. Table 1 shows the effects of PA on shoot number and increased rate of shoots in fresh mass. Shoot proliferation and fresh weight of multiplied shoots increased in the proliferation medium without PA. All of the cultivars were inhibited by adding PA, but especially 'Hosui'. The inhibitory effect on fresh weight tended to increase with increasing PA concentration. Regression analysis indicated that the shoot number was related to increasing the PA concentration in 'Kosui' and the fresh weight increase was related to the PA concentration in 'Hosui' and 'Shinko'.

Our results disagreed with previous studies in which PA improved the growth of a few plants (Ichikawa and Ota, 1982; Shirakawa et al., 1995a; Yatagai and Unrinin, 1987). These results might be related to the effects of PA on plant growth, however, the effects differed depending on the plant species (Uehara at el., 1993; Yatagai and Unrinin, 1987). Perhaps the refining treatment of PA, such as activated charcoal, accelerates the growth (Yatagai and Unrinin, 1987).

Survival rate, rooting, and root length. Table 2 shows the effect of PA on the survival rate of shoots, number of shoots forming roots and the average length of roots in Japanese pear cultivars. The four PA concentrations had no effect on the survival of explants of the three cultivars. PA stimulated rooting, with optimum concentrations at $0.01 \%$ and $0.1 \%$ for 'Hosui' and $0.1 \%$ for 'Kosui' and 'Shinko', whereas PA had no effect on root growth. Regression analysis indicated that the rooting frequency was related to the PA concentration for 'Kosui' and 'Shinko'.

Shirakawa et al., (1995b) reported that the main components of organic acids and phenols contained in PA affect the growth of rice plants. They found that some organic acids, such as isocaproic acid (4-methylvaleric acid), caproic acid (n-caproic acid) and tiglic acid [(E)-2-methyl-2-butenoic acid], and some phenols, such as 2,6-dimethoxyphenol, 4ethylphenol, and guaiacol (o-methoxyphenol), accelerate root growth at each $10 \mathrm{ppm}$. Furthermore, they compared the effect of each organic acid or phenol with PA treatment and suggested that organic acids and phenols in PA are synergistic in PA treatment because the effects of organic acids and phenols treated alone were inferior to PA treatment. Many studies have been undertaken to improve rooting in Pyrus sp. (Bertazza et al., 1995; Reed, 1995; Rodríguez 
Table 1. Effect of pyroligneous acid (PA) on shoot proliferation of Japanese pear ${ }^{2}$

\begin{tabular}{|c|c|c|c|c|c|c|}
\hline \multirow{2}{*}{$\begin{array}{l}\text { Concn. of PA (v/v) } \\
(\%)\end{array}$} & \multicolumn{3}{|c|}{ Mean no. shoots formed per explant } & \multicolumn{3}{|c|}{ Fresh wt increase from initial wt (\%) } \\
\hline & Hosui & Kosui & Shinko & Hosui & Kosui & Shinko \\
\hline 0 & $2.3 \mathrm{a}^{\mathrm{y}}$ & $3.8 \mathrm{a}$ & $2.7 \mathrm{a}$ & $799 a$ & $865 \mathrm{a}$ & $888 \mathrm{a}$ \\
\hline 0.001 & $1.6 \mathrm{c}$ & $3.5 \mathrm{a}$ & $2.9 \mathrm{a}$ & $483 \mathrm{bc}$ & $781 \mathrm{a}$ & $901 \mathrm{a}$ \\
\hline 0.01 & $1.7 \mathrm{bc}$ & $2.8 \mathrm{a}$ & $2.1 \mathrm{~b}$ & $557 \mathrm{~b}$ & $607 \mathrm{~b}$ & $709 \mathrm{~b}$ \\
\hline 0.1 & $1.9 \mathrm{~b}$ & $2.9 \mathrm{a}$ & $2.3 \mathrm{~b}$ & $376 \mathrm{c}$ & $671 \mathrm{ab}$ & $661 \mathrm{~b}$ \\
\hline \multicolumn{7}{|l|}{ Significance } \\
\hline Concn. & & NS & & & $* *$ & \\
\hline Cultivar & & $* *$ & & & ** & \\
\hline \multirow{2}{*}{$\begin{array}{l}\text { Concn. } \times \text { cultivar } \\
\text { Regression analysis }\end{array}$} & & NS & & & $* *$ & \\
\hline & $\begin{aligned} \mathrm{y}_{1}= & 4.7^{-3} \mathrm{x} \\
& -1.2^{-3} \mathrm{x}^{2} \\
& +2.4^{-2} \\
\left(r^{2}=\right. & \left.0.02^{\mathrm{ss}}\right)\end{aligned}$ & $\begin{array}{c}\mathrm{y}_{1}=3.4^{-2} \mathrm{x} \\
-5.0^{-3} \mathrm{x}^{2} \\
-2.1^{-2} \\
\left(r^{2}=0.32^{* *}\right)\end{array}$ & $\begin{array}{c}\mathrm{y}_{1}=-1.6^{-2} \mathrm{x} \\
-1.5^{-3} \mathrm{x}^{2} \\
-1.5^{-3} \\
\left(r^{2}=0.18^{\mathrm{Ns}}\right)\end{array}$ & $\begin{aligned} \mathrm{y}_{2}= & -2.7^{-4} \mathrm{x} \\
& +1.46 \mathrm{x}^{2} \\
& +1.3^{-1} \\
\left(r^{2}=\right. & \left.0.56^{* *}\right)\end{aligned}$ & $\begin{aligned} \mathrm{y}_{2}= & -1.1^{-4} \mathrm{x} \\
& -4.08 \mathrm{x}^{2} \\
& +0.8^{-1} \\
\left(r^{2}=\right. & \left.0.23^{\mathrm{s}}\right)\end{aligned}$ & $\begin{aligned} \mathrm{y}_{2}= & -2.1^{-4} \mathrm{x} \\
& +5.7 \mathrm{x}^{2} \\
& +1.6^{-1} \\
\left(r^{2}=\right. & \left.0.50^{* *}\right)\end{aligned}$ \\
\hline
\end{tabular}

${ }^{2}$ Fresh mass of shoot tips of each cultivars at the start of the experiment were 17.5 $\pm 0.8 \mathrm{mg}$ in Hosui, $22.9 \pm 0.9 \mathrm{mg}$ in Kosui, and 20.1 $\pm 0.8 \mathrm{mg}$ in Shinko.

${ }^{y}$ Mean separation with in the same cultivar by LSD at $P \leq 0.05$.

${ }^{x} y_{1}, y_{2}$, and $x$ indicate no. of shoots formed by each explant, rate of fresh weight increase (\%) and concn. of PA (\%), respectively.

Ns, ** Nonsignificant or significant at $P \leq 0.01$.

Table 2. Effect of pyroligneous acid (PA) on in vitro rooting of Japanese pear.

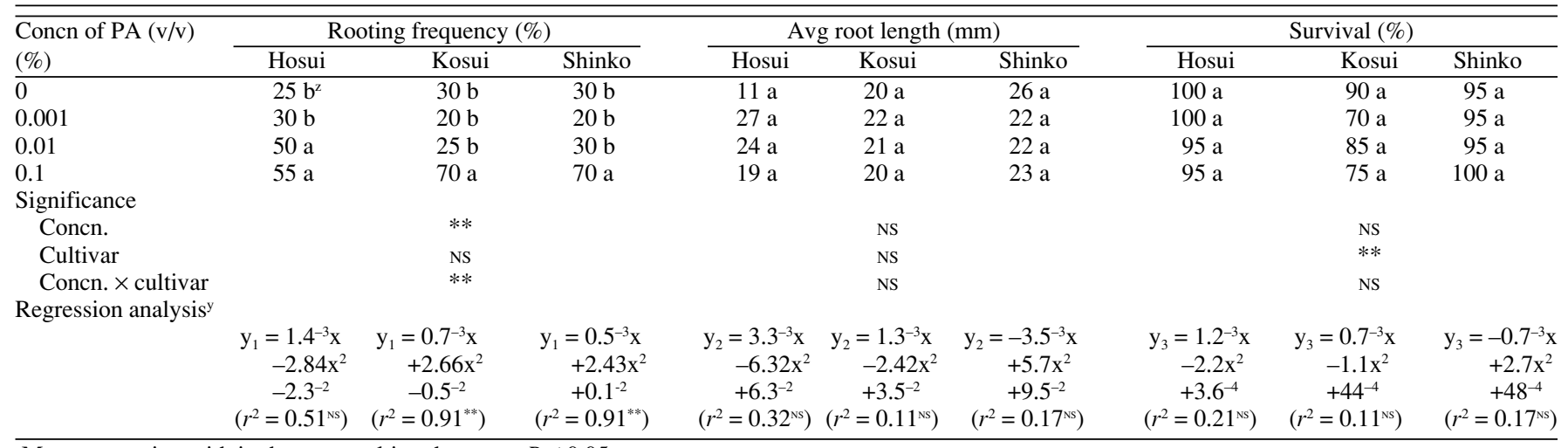

${ }^{2}$ Mean separation with in the same cultivar by LSD at $P \leq 0.05$.

${ }^{\mathrm{y}} \mathrm{y}_{1}, \mathrm{y}_{2} \mathrm{y}_{3}$ and $\mathrm{x}$ indicate rooting frequency (\%), average root length, survival rate (\%) and concn. of PA (\%), respectively.

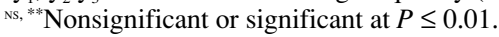

et al., 1991; Wang, 1991, 1992; Yeo and Reed, 1995), but most did not study Japanese pear. The results of this study clearly show that PA improved Japanese pear rooting in vitro. We are now studing the effect of PA on rooting in other woody rosaceous species and the specific components of PA that accelerate the rooting processes.

\section{Literature Cited}

Bertazza, G., R. Baraldi, and S. Predieri. 1995. Light effects on in vitro rooting of pear cultivars of different rhizogenic ability. Plant Cell Tissue Organ Cult. 41:139-143.

Du, H.G., E. Mori, H. Terao, and E. Tsuzui. 1998. Effect of the mixture of charcoal with pyroligneous acid on shoot and root growth of sweet potato. Jpn. J. Crop Sci. 67:149-152. (in Japanese with English summary).

Ichikawa, T. and Y. Ota. 1982. Plant growth-regulating activity of pyroligneous acid I. Effect of pyroligneous acid on the growth of rice seedling. Jpn. J. Crop Sci. 51:14-17. (in Japanese with
English summary and table).

Jodai, S., S. Yano, and T. Uehara. 1989. Components of wood-vinegar liquors and their smoke flavors. Mokuzai Gakkaishi. 35:555-563. (in Japanese with English summary and table).

Murashige, T. and F. Skoog. 1962. A revised medium for rapid growth and bioassays with tobacco tissue cultures. Physiol. Plant. 15:473-497.

Reed, B.M. 1995. Screening Pyrus germplasm for in vitro rooting response. HortScience. 30:12921294.

Rodríguez, R., C. Díaz-Sala, L. Cuozzo, and G. Ancora. 1991. Pear in vitro propagation using a double-phase culture system. HortScience. 26:62-64.

Shirakawa, N., T. Ichikawa, R. Koyama,H. Taniguchi, S. Honma, S. Terada. 1995a. Effect of pyroligneous acid on the growth of rice. Agr. and Hort. 70:806-808, 899-903. (in Japanese).

Shirakawa, N., M. Fukasawa, and S. Terada . 1995b. Effect of the main components including in pyroligneous acid on the growth of rice. Agr. and Hort. 70:1107-1111, 1217-1222. (in Japanese).

Tsuzuki, E., Y. Wakiyama, H. Eto, and H. Handa. 1989. Effect of pyroligneous acid and mixture of charcoal with pyroligneous acid on the growth and yield of rice plant. Jpn. J. Crop Sci. 58:592597. (in Japanese with English summary).

Uehara, T., Y. Horio, T. Furuno, and S. Jodai. 1993. Effect of wood vinegars on germination and radicle growth of seed plants. Mokuzai Gakkaishi. 39:1415-1420. (in Japanese with English summary and table).

Wang, Q.C. 1991. Factors affecting rooting of microcuttings of the pear rootstock BP10030. Sci. Hort. 45:209-213.

Wang, Q.C. 1992. The effect of light, darkness and temperature on micropropagation of the pear rootstock BP10030. J. Hort. Sci. 67:869-876.

Yatagai, M., and G. Unrinin. 1987. By-products of wood carbonization III: Germination and growth acceleration effects of wood vinegars on plant seeds. Mokuzai Gakkaishi. 33:521-529.

Yatagai, M., G. Unrinin, and T. Ohira. 1988. Byproducts of wood carbonization VI: Components of wood vinegars. Mokuzai Gakkaishi. 34:184-188.

Yeo, D.Y. and B.M. Reed. 1995. Micropropagation of three Pyrus rootstocks. HortScience 30:620623. 